\title{
자동 $\mathrm{ABLB}$ 검사 소프트웨어 개발 \\ 강덕훈 $^{1}$, 김진동 ${ }^{2}$, 송복득 $^{1}$, 신범주 $^{1^{*}}$, 왕수건 $^{3}$ \\ ${ }^{1}$ 부산대학교 생명자원대학 바이오메디컬공학과, ${ }^{2}$ 부산대학교 의과대학 의공학교실, \\ ${ }^{3}$ 부산대학교 의과대학 이비인후과교실
}

\section{Development of an Auto ABLB Test Software}

\author{
Deok-Hun Kang ${ }^{1}$, Jin-Dong Kim ${ }^{2}$, Bok-Deuk Song ${ }^{1}$, Bum-Joo Shin ${ }^{1 *}$ \\ and Soo-Geun Wang ${ }^{3}$ \\ ${ }^{1}$ Department of Biomedical Engineering, College of Natural Resource and Life Science, Pusan \\ National University \\ $\left\{^{2}\right.$ Department of Biomedical Engineering, ${ }^{3}$ Department of Otolaryngology\}, School of Medicine, Pusan \\ National University
}

요 약 $\mathrm{ABLB}$ (양측 귀 교대 평형) 검사는 누가현상에 기초한 감각신경성 난청의 세부 병변을 감별하기 위한 검사 중 하나이다. 본 논문은 자동 $\mathrm{ABLB}$ 검사 소프트웨어를 기술한다. 이 소프트웨어는 $\mathrm{ABLB}$ 검사 주파수 및 검사 시작 음을 자동으로 결정한다. 또한 검사 음에 대한 피검자의 반응을 분석하여 다음 검사를 결정하는 알고리즘을 지원한 다. 또, 피검자의 $\mathrm{ABLB}$ 검사 제어 및 모니터링을 위한 인터페이스를 제공하고 검사 결과를 Ladder Diagram으로 나 타낸다. 디지털 오실로스코프를 이용하여 ABLB 검사 음이 정확하게 출력되는지 확인하였다.

\begin{abstract}
ABLB(Alternate Binaural Loudness Balance) test is one of the medical assessments to diagnose detailed lesion of sensory-neural hearing loss based on a recruitment phenomenon. This paper describes an Auto ABLB test software. This software automatically decides test frequency and intensity of first test tone. And it supports an automatic algorithm that analyses the subject's reponses in the current step and then decides intensity of tone provided in next step. Also, this software supports an interface to control and monitor subject's ABLB test. The assessment result is represented by a ladder diagram. The output of this software has been verified using a digital oscilloscope.
\end{abstract}

Key Words : ABLB, Alternate Binaural Loudness Balance, Audiometer

\section{1. 서론}

컴퓨터 하드웨어의 발전, 특히 사운드 카드의 발전은 기존의 전용 전자기기로만 제공되던 청력검사 장비를 PC 환경의 컴퓨터 소프트웨어로 구현 가능하도록 하고 있으 며, 다양한 연구들이 시도 되고 있다.[1,2,3,4,5,6]

청력검사 시스템을 컴퓨터 소프트웨어로 구현 할 경우 여러 가지 장점들을 가진다. 구체적으로 다양한 청력검사 기능을 쉽게 지원 할 수 있으며, 검사자의 기술에 의존하
지 않는 자동 검사 기능을 제공 할 수 있다. 또한 컴퓨터 의 표준 입·출력 인터페이스들을 통해 쉽게 시스템을 확 장 할 수 있을 뿐만 아니라 청력검사 전용기기에 비해 가 격 경쟁력을 가지는 장점이 있다.

본 논문에서는 누가현상을 이용하여 미로성 난청의 감 별 진단에 도움이 되는 $\mathrm{ABLB}$ (양측 귀 교대 평형) 검사를 자동으로 수행할 수 있는 청력검사 시스템을 컴퓨터를 기반으로 구현한다. 누가현상이란 인간이 들을 수 있는 음의 강도(intensity)의 범위를 의미하는 가청음역이 축소

이 논문은 2010년도 정부(교육과학기술부)의 재원으로 한국과학재단의 지원을 받아 수행된 연구임(No.2010-0027658).

"교신저자 : 신범주(bjshin@pusan.ac.kr)

접수일 10 년 10 월 18 일

수정일 (1차 10년 11월 15일, 2차 10년 12월 21일)

게재확정일 10 년 12 월 17 일 
되어 역동범위가 좁아지는 현상을 의미한다. 즉, 귀로 들 을 수 있는 최저 음의 강도와 최고 음의 강도 폭이 좁아 지게 되고 결과적으로 작은 음의 강도 변화를 매우 큰 음 의 강도 변화로 인지하는 증상이다.[7]

$\mathrm{ABLB}$ 검사는 순음청력검사 결과를 바탕으로 양쪽 귀 의 기도역치가 적어도 $20 \mathrm{~dB} \mathrm{HL(Hearing} \mathrm{Level)} \mathrm{이상} \mathrm{차}$ 이가 나는 주파수에서 검사를 진행한다. 주파수가 선택되 면 기준 귀에 들려주는 음의 강도를 역치보다 $20 \mathrm{~dB}$ 높은 강도로 고정시키고, 가변 귀의 음의 강도를 변화시키며 양쪽 귀가 동일한 크기로 인지하는 음의 강도를 찾는다. 이후 기준 귀의 음의 강도를 $20 \mathrm{~dB}$ SL(Sensation Level) 간격으로 증가 시킨 후 같은 방법으로 가변 귀에서 동일 하게 인지하는 음의 크기를 찾는다. 선택된 주파수에서 기준 귀의 음의 강도가 정상인의 청력으로 듣기에 불쾌 하게 느껴지는 불쾌역치까지 검사를 계속 수행한 후 다 른 주파수에서 앞서 기술한 순서로 검사를 수행한다. 검 사가 완료되면 피검자가 양쪽 귀에서 동일한 크기로 인 지하는 음의 강도를 그래프로 보여준다.[7]

앞서 설명한 $\mathrm{ABLB}$ 검사를 자동으로 수행하기 위해서 는 기본적으로 다음의 기능이 요구된다. 첫째는 $\mathrm{ABLB}$ 검사 주파수를 자동으로 선택할 수 있어야 하고, 피검자 의 양쪽 귀에 동일한 주파수의 단속음을 다른 강도로 들 려 줄 수 있어야 한다. 둘째는 양쪽 귀에 주어지는 음의 강도를 $\mathrm{ABLB}$ 검사 알고리즘과 피검자의 반응에 따라 자 동으로 결정하는 메카니즘을 제공하여야 한다. 마지막으 로 $\mathrm{ABLB}$ 검사 결과를 Ladder Diagram을 통해 시각적으 로 쉽게 나타낼 수 있어야 한다.

본 논문은 선행 연구인 다중모드 및 자동차폐를 지원 하는 순음청력검사 시스템[3]과 누가현상을 이용하는 검 사 방법 중 하나인 SISI(미세증가감수지수) 검사 시스템 [5]에 추가하여 미로성 난청을 진단하기 위해 사용하는 $\mathrm{ABLB}$ 검사를 자동으로 수행할 수 있는 컴퓨터 소프트웨 어의 구현에 대해 기술한다.

\section{2. 관련 연구}

본 연구와 관련된 연구는 크게 두 가지로 구분된다. 첫 째는 전용 전자기기인 청력검사 장비를 대체하는 컴퓨터 를 이용한 청력검사 시스템에 관한 연구이며, 둘째는 $\mathrm{ABLB}$ 검사 기능 구현에 관한 연구이다.

컴퓨터 기반 청력검사 시스템에 관한 연구는 다음과 같다. 신승원 외 4인[1]은 $\mathrm{PDA}$ 를 이용하여 기도 순음청 력검사와 어음청력검사를 제공하는 이동형 청력검사 시 스템을 개발 하였고, 이동훈 외 7인[2]은 웹 기반으로 PC
에서 운영되는 기도 순음청력검사 시스템을 개발하였다. 신승원 외 4 인[1]의 연구는 휴대성과 어음청력검사 기능 제공의 장점이 있지만 최소가청역치를 구하는 순음청력 검사 기능만을 제공하고 있고, 이동훈 외 7인[2]의 연구 또한 웹 기반의 순음청력검사 기능을 제공하고 있으나 최소가청역치를 구하는 순음청력검사 기능만을 제공하고 있다는 점에서 본 연구와 차별된다.

$\mathrm{ABLB}$ 검사 기능 구현과 관련된 기존의 연구는 다음 과 같다. Interacoustics의 $\mathrm{AC} 40[8]$ 과 $\mathrm{GSI}$ 의 GSI61[9]은 $\mathrm{ABLB}$ 검사 기능을 제공하고 있으며, 현재 국내·외 의료 기관에서 널리 사용되고 있는 청력검사 전용기기이다. 그 러나 이들 기기는 $\mathrm{ABLB}$ 검사 주파수 선정 및 음의 강도 결정을 자동으로 제공하지 않고, $\mathrm{ABLB}$ 검사 방법 또한 검사자의 주관적인 판단으로 진행된다. 따라서 피검자의 $\mathrm{ABLB}$ 검사 결과를 검사자의 $\mathrm{ABLB}$ 검사 방법에 의존하 는 단점을 가진다.

반면 본 논문의 자동 $\mathrm{ABLB}$ 검사 소프트웨어는 검사 음의 주파수 선정 및 음의 강도에 대한 결정을 피검자의 반응 및 검사 알고리즘에 따라 자동으로 제공한다. 따라 서 $\mathrm{ABLB}$ 검사 결과의 정확성 및 신뢰성을 향상 시킬 수 있을 뿐만 아니라, 컴퓨터 기반의 시스템으로 유연성 및 가격 경쟁력을 제공한다는 장점을 가진다.

\section{3. 설계 및 구현}

일반적으로 검사자가 피검자의 순음청력검사를 수행 한 후 기도역치 결과를 눈으로 확인하고, 이 결과를 바탕 으로 $\mathrm{ABLB}$ 검사 주파수 선정 및 검사 음의 강도를 결정 하여 $\mathrm{ABLB}$ 검사를 진행한다. 그리고 피검자의 검사 음 에 대한 반응을 검사자가 판단하고 검사 음을 재설정한 후 동일한 검사 과정을 반복 수행하게 된다. 이와 같은, 검사를 수동 $\mathrm{ABLB}$ 검사라 한다.

반면 본 논문의 자동 $\mathrm{ABLB}$ 검사 소프트웨어는 피검 자의 순음기도역치 결과를 분석하여 검사가 필요한 주파 수를 자동으로 선정한다. 선정된 주파수들 중 하나의 주 파수를 선택하고 해당 주파수의 기도역치 값을 기준으로 Jerger 검사 방법과 Hood 검사 방법에 따라 기준 귀와 가 변 귀의 검사 음의 강도를 자동으로 결정한다. 그리고 피 검자에게 검사 음을 들려준 후 피검자의 반응을 분석하 여 다음 검사를 검사 알고리즘에 따라 진행한다.

자동 $\mathrm{ABLB}$ 검사를 위해서는 피검자에게 $\mathrm{ABLB}$ 검사 가 필요한 주파수 선정, 기준 귀와 가변 귀에 들려줄 음 의 강도 결정, 피검자의 반응을 분석한 후 다음 검사의 진행을 결정하는 알고리즘이 요구된다. 그리고 검사 결과 
에 따른 Ladder Diagram 출력과 검사자가 피검자의 검사 진행 상황을 확인 할 수 있는 사용자 인터페이스 등이 요 구된다.

본 장에서는 자동 $\mathrm{ABLB}$ 검사 소프트웨어의 설계 및 구현 내용에 대해 기술한다.

\subsection{ABLB 검사 음 생성}

$\mathrm{ABLB}$ 검사에서 사용하는 기본 단속음의 생성은 순음 청력검사 시스템[3]의 순음 생성 과정을 기본으로 한다. 순음 생성을 위해서 $44100 \mathrm{sample} / \mathrm{sec}$ 주파수로 샘플링 된 24 비트 PCM 포맷을 이용한다. 검사 음의 빈번한 주 파수와 음의 강도 변화에 대처하기 위해 수식 1.1 을 이용 하여 $1 \mathrm{~Hz}$ 의 기본 정현파 데이터를 가지는 룩업테이블을 생성한다. 그리고 룩업테이블에서 정해진 주파수 간격으 로 값을 추출하여 음의 강도를 곱하여 검사 음을 생성한 다. 수식 1.2 는 음을 생성하기 위해 사용된 함수를 나타 낸다.[3]

$$
\begin{gathered}
y(n)=\sin \left(2 \pi \frac{n}{f_{s}}\right) \\
y(n)=A \cdot \sin \left(2 \pi f \frac{n}{f_{s}}\right) \\
f: \text { frequency } \\
f_{s}: \text { sampling rate } \\
n: n^{\text {th }} \text { sample }
\end{gathered}
$$

$\mathrm{ABLB}$ 검사에서 사용하는 기본 단속음은 그림 1 과 같 다. 그림 1 에서 수평축은 시간 축을 나타내고 수직축은 음의 강도(dB HL)를 나타낸다. 상기 수식 1.2에서 볼 수 있듯이 음의 강도는 순음의 진폭에 비례하게 된다. 따라 서 그림 1의 Plateau 구간은 순음의 진폭과 비례하게 된다.

청력검사기의 검사음에 대한 Rise와 Fall 구간의 시간 은 ANSI S3.6-2004[10]의 표준 규격을 준수하도록 $20 \mathrm{~ms}$ 이상인 $50 \mathrm{~ms}$ 로 설정하였다. 그리고 Plateau 구간은 $400 \mathrm{~ms}$ 로 $\mathrm{ABLB}$ 기본 단속음의 총 시간은 일반적인 $\mathrm{ABLB}$ 기본 단속음의 길이인 $500 \mathrm{~ms}$ 의 시간을 가진다.

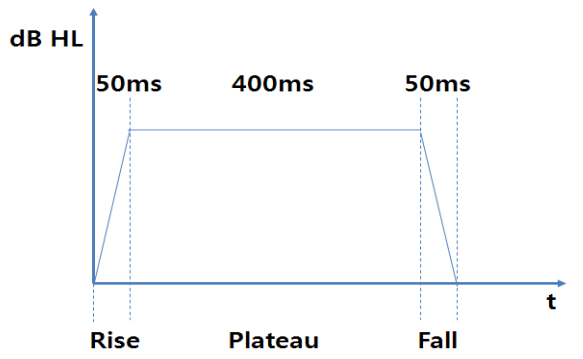

[그림 1] ABLB 기본 단속음
순음청력검사에서는 난청의 유무를 검사하기 위해 한 쪽 귀에만 순음을 들려주지만 ABLB 검사는 양쪽 귀 모 두에 음의 강도가 다른 순음을 들려준다. 따라서 앞서 기 술한 기본 단속음을 기준 귀부터 들려주며 1초 주기로 양 쪽 귀에 교대로 단속음을 들려준다. 그림 2 는 본 논문에 서 구현한 소프트웨어가 ABLB 검사 음을 양쪽 귀에 어 떻게 들려주는지 나타낸다.

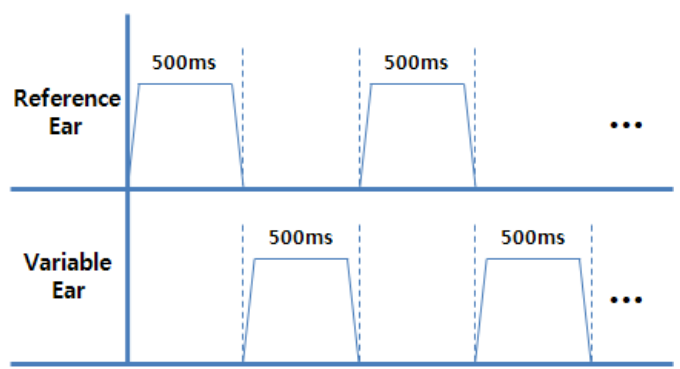

[그림 2] $\mathrm{ABLB}$ 검사 음

\section{2 검사 알고리즘}

$\mathrm{ABLB}$ 검사는 양쪽 귀의 순음기도전도역치 값을 바탕 으로 진행하는 검사이며 일반적으로 순음청력검사에서 사용하는 주파수보다 좁은 대역인 $500 \mathrm{~Hz}$ 에서 $4 \mathrm{KHz}$ 사 이의 주파수에서 검사를 진행한다. 본 논문에서 구현한 소프트웨어는 병원에서 $\mathrm{ABLB}$ 검사를 하는 동안 가장 일 반적으로 검사하는 $1 \mathrm{KHz}, 2 \mathrm{KHz}, 4 \mathrm{KHz}$ 의 주파수를 지원 한다. 그러나 본 시스템에서는 사용 가능 주파수를 쉽게 변경할 수 있다.

\subsubsection{ABLB 검사 주파수 선정}

$\mathrm{ABLB}$ 검사를 진행하기 전에 가장 먼저 순음청력검사 의 순음기도전도역치 값으로 $\mathrm{ABLB}$ 검사가 필요한 주파 수를 선정한다. 각 주파수에서 한쪽 귀의 역치 값이 정상 이거나 약간의 감각신경성 난청이 존재하고 반대 쪽 귀 의 역치 값이 $20 \mathrm{~dB}$ 이상 차이가 나는 경우 해당 주파수 에서 $\mathrm{ABLB}$ 검사를 수행한다.

\subsection{2 기준 귀 및 가변 귀 설정}

검사가 필요한 주파수가 선정되면 Jerger 검사 방법과 Hood 검사 방법에 따라 청력이 좋은 쪽 귀와 청력이 나 쁜 쪽 귀 중 하나를 기준 귀(reference ear)로 설정하고 기 준 귀의 반대 쪽 귀를 가변 귀(variable ear)로 설정한다. Jerger 검사 방법은 청력이 나쁜 쪽 귀를 기준 귀로 결정 하고 Hood 검사 방법은 청력이 좋은 쪽 귀를 기준 귀로 결정하는 방법이다. 본 시스템은 기본적으로 Hood 검사 
방법으로 ABLB 검사를 수행하고 Hood 및 Jerger 검사 방법 선택은 $\mathrm{ABLB}$ 검사 인터페이스에서 체크박스 컨트 롤로 간단하게 변경 가능하도록 하였다.

\subsection{3 검사 시작 음의 강도 설정}

기준 귀가 결정 되면 검사를 위한 기준 귀와 가변 귀 의 음의 강도를 자동으로 결정한다. 기준 귀는 검사를 하 는 동안 고정된 음의 강도를 가지고 가변 귀는 피검자의 $\mathrm{ABLB}$ 검사음에 대한 반응에 따라 음의 강도를 증가하거 나 감소한다.

기준 귀와 가변 귀의 검사 시작 음의 강도는 $20 \mathrm{~dB} \mathrm{SL}$ 간격으로 증가 시킨다. 따라서 기준 귀와 가변 귀의 각 역치 값에 $+20 \mathrm{~dB},+40 \mathrm{~dB},+60 \mathrm{~dB}$ 단계로 검사 시작 음의 강도를 결정한다.

$\mathrm{ABLB}$ 검사는 한쪽 귀가 정상이거나 약간의 감각신경 성 난청이 있을 경우에 수행하는 검사이므로 너무 높은 강도의 검사 음을 들려주면 피검자의 청력을 손상시킬 수 있다. 그러므로 정상인의 청력으로 듣기에는 불쾌한 음의 강도인 불쾌역치를 고려하여 $90 \mathrm{~dB} \mathrm{HL}$ 을 최대 검사 음의 강도로 설정하였다. 만약 기준 귀와 가변 귀 중 하 나의 검사 시작 음의 강도가 $90 \mathrm{~dB} \mathrm{HL}$ 를 초과 할 경우 해 당 주파수 검사를 종료한다.

\subsubsection{ABLB 검사 진행}

본 논문의 자동 $\mathrm{ABLB}$ 검사는 피검자의 검사 음에 대 한 반응에 따라 실시간으로 가변 귀의 음의 강도를 $\pm 5 \mathrm{~dB}$ 단위로 변경한다. $\pm 5 \mathrm{~dB}$ 보다 작은 값으로 음의 강도를 변경할 경우 검사 시간이 오래 걸릴 뿐만 아니라 피검자 가 지루하게 느껴 동일하게 느끼는 음의 강도를 인지하 기 어렵기 때문이다.

피검자가 기준 귀보다 가변 귀의 검사 음이 더 크다고 반응하면 가변 귀의 음의 강도를 $5 \mathrm{~dB}$ 감소시키고 반대의 경우 $5 \mathrm{~dB}$ 증가시켜 재검사를 수행한다. 만약 피검자가 양쪽 귀의 검사 음의 크기가 동일하다고 두 번 연속 반응 하면 검사 결과를 Ladder Diagram에 출력 한 후 검사를 종료한다. 검사 수행 중 가변 귀의 검사 음의 강도가 $90 \mathrm{~dB} \mathrm{HL}$ 를 초과하면 불쾌역치를 고려하여 검사를 종료 한다. 그림 3 은 자동 $\mathrm{ABLB}$ 검사 순서도를 나타낸다.

\section{3 피검자의 입력}

$\mathrm{ABLB}$ 검사는 기준 귀의 음의 강도를 가변 귀의 음의 강도와 비교하여 동일하게 들리는 음의 크기를 찾는 검 사이다. 하지만 피검자는 기준 귀가 어느 쪽 귀인지 그리 고 가변 귀가 어느 쪽 귀인지 알 수 없다. 그러므로 피검
자는 검사 음이 크게 들리는 쪽의 입력 버튼을 누르도록 한다. 따라서 왼쪽 귀의 검사 음이 큰 경우, 오른쪽 귀의 검사 음이 큰 경우, 양쪽 귀의 검사 음이 동일한 경우에 대한 3 개의 입력 버튼을 피검자에게 제공한다.

본 논문에서 구현한 소프트웨어는 불쾌역치를 고려하 여 $90 \mathrm{~dB} \mathrm{HL}$ 을 최대 검사 음의 강도로 설정 하였다. 하지 만 $90 \mathrm{~dB} \mathrm{HL}$ 이하의 검사 음도 피검자는 불쾌한 검사 음 으로 인지 할 수 있으므로 이런 상황에 대비하여 피검자 에게 검사를 일시 중지 할 수 있는 입력 버튼을 제공한 다. 따라서 피검자에게는 총 4 개의 입력 버튼을 제공한다.

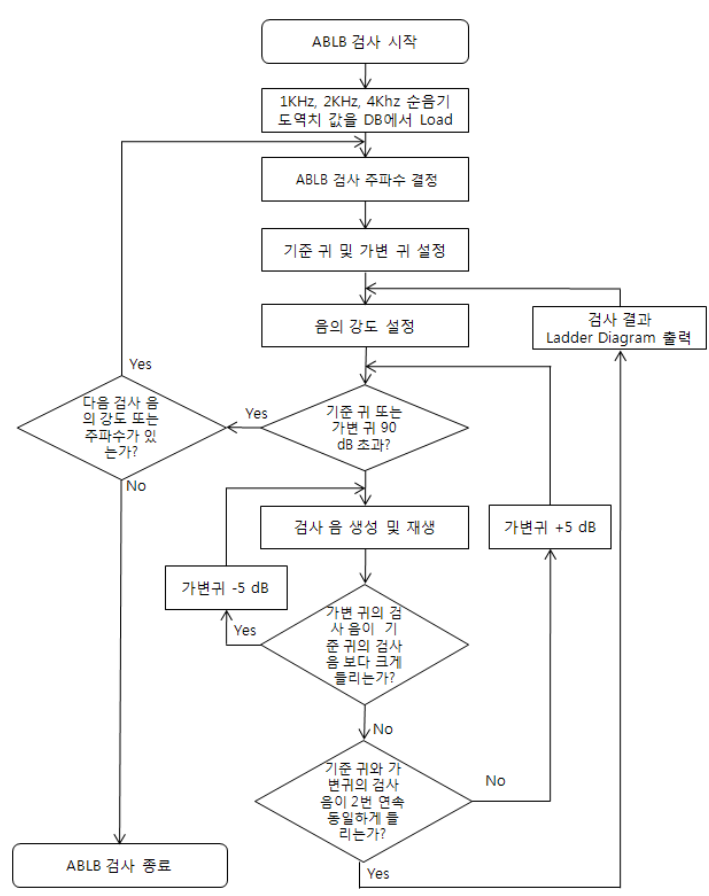

[그림 3] 자동 ABLB 검사 순서도

\section{4 피검자의 반응에 대한 가변 귀의 음의 강도}

가변 귀의 음의 강도 결정을 위해서는 두 가지 사항을 고려한다. 우선 기준 귀가 어느 쪽 귀인지 그리고 피검자 의 입력이 왼쪽인지 오른쪽인지를 구분한다. 만약 피검자 가 검사를 하는 동안 기준 귀와 같은 쪽 귀의 버튼을 누 르면 가변 귀의 음의 강도를 $5 \mathrm{~dB}$ 증가시키고 기준 귀와 다른 쪽 귀의 버튼을 누르면 가변 귀의 음의 강도를 $5 \mathrm{~dB}$ 감소시킨다.

\section{5 사용자 인터페이스}

\subsection{1 청력검사 소프트웨어의 검사 기능}

본 논문은 기존의 순음청력검사 소프트웨어를 확장하 
여 $\mathrm{ABLB}$ 검사 기능을 제공한다. 본 시스템이 제공됨으 로써 그림 4에 나타난 구조를 갖는 청력검사 소프트웨어 가 제공된다. 그림 4 의 순음청력검사와 SISI 검사는 각각 세 가지 모드를 제공하고 있다. 반면 ABLB 검사는 자동 모드만을 제공한다. SISI 검사와 ABLB 검사는 순음청력 검사가 선행되어야 검사가 가능하며 검사 수행 여부는 검사자의 판단에 따른다.

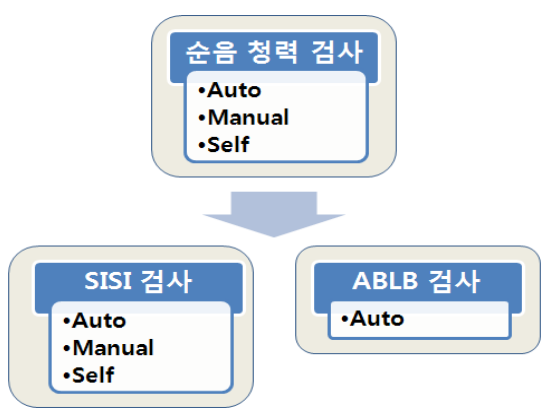

[그림 4] 청력검사 소프트웨어 구조

\subsection{2 자동 ABLB 검사 인터페이스}

자동 $\mathrm{ABLB}$ 검사를 진행하는 동안 피검자는 방음실에 서 헤드폰으로 출력되는 검사 음에 대해 입력 장치로 반 응한다. 그리고 이 때 발생하는 이벤트는 $\mathrm{ABLB}$ 검사 소 프트웨어가 설치된 $\mathrm{PC}$ 로 전달되고 $\mathrm{ABLB}$ 검사 알고리즘 에 의해 처리된다. 본 논문의 자동 $\mathrm{ABLB}$ 검사 소프트웨 어는 검사자에게 피검자의 검사 제어 및 모니터링을 위 한 편리한 인터페이스를 제공한다.

자동 $\mathrm{ABLB}$ 검사 인터페이스는 검사자가 검사를 제어 하기 위한 검사 시작, 일시정지, 정지 버튼 컨트롤들과 검 사 음과 피검자의 반응에 대한 검사 진행 상황을 보여주 는 램프들 그리고 검사 음에 대한 정보를 출력하는 컨트 롤들이 있다. 마지막으로 $\mathrm{ABLB}$ 검사 결과를 출력하기 위한 Ladder Diagram을 제공한다. 그림 5는 자동 $\mathrm{ABLB}$ 검사 인터페이스를 보여준다.

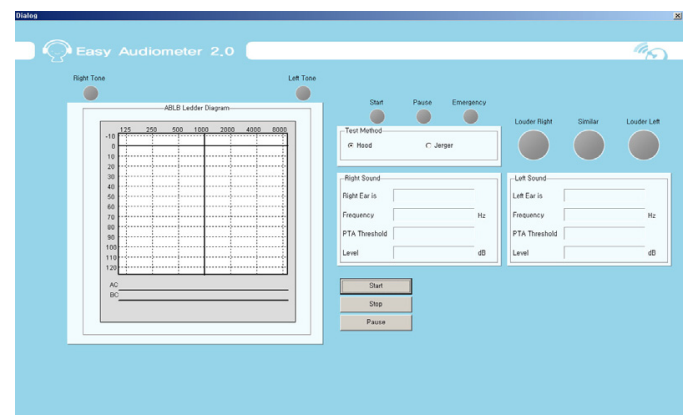

[그림 5] 자동 ABLB 검사 인터페이스
검사자가 검사 시작 버튼을 누르면 검사 음이 발생되 고 검사가 진행됨을 램프로 표시한다. 검사 음은 양쪽 귀 에 교대로 발생하고 음이 발생하는 쪽의 램프가 표시되 며 검사 음의 정보가 화면에 나타난다. 만약 피검자가 검 사 음에 대한 반응으로 버튼을 누르게 되면 해당 버튼을 램프로 표시한다. 피검자가 양쪽 귀의 음의 크기가 동일 하다고 두 번 연속 반응하면 Ladder Diagram에 결과를 출력하고 다음 검사를 진행한다. 그림 6 은 검사가 종료 된 후 Ladder Diagram에 출력된 검사 결과를 보여준다.

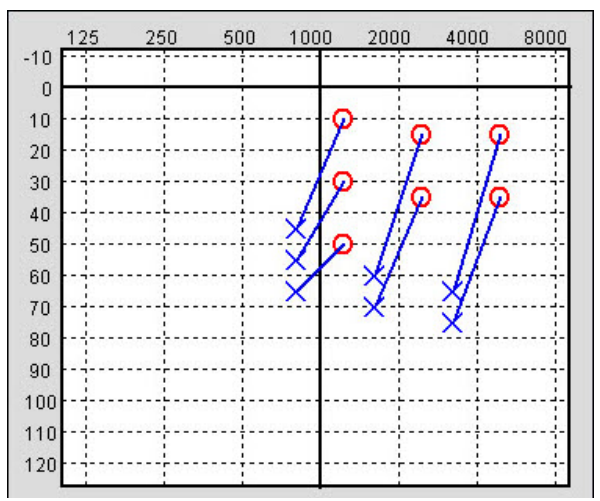

[그림 6] 자동 $\mathrm{ABLB}$ 검사 다이얼로그

\section{4. 시험 및 결과 평가}

\section{1 시험 환경}

자동 $\mathrm{ABLB}$ 검사 소프트웨어는 Intel Core2 Duo $\mathrm{E} 74002.8 \mathrm{GHz}$ 프로세서, Audiophile 2496 사운드 카드를 사용하였고 Windows XP 운영체제 기반의 $\mathrm{PC}$ 를 사용하 였다. 검사 음의 출력을 위한 헤드폰은 Telephonics사의

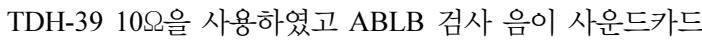
의 출력 채널에서 제대로 출력되는지 확인하기 위해 Tektronix사의 4032 디지털 오실로스코프를 사용하였다.

\section{2 시험 결과 및 평가}

그림 $7,8,9$ 는 사운드카드의 단일 출력 채널에서 출력 되는 기본 단속음의 Rise, Fall, Plateau 구간을 오실로스 코프로 측정한 화면 일부분을 나타낸다. 


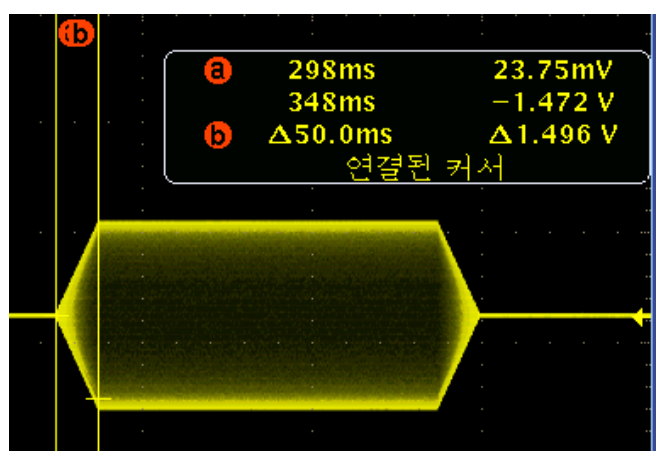

[그림 7] 기본 단속음 Rise 구간 측정

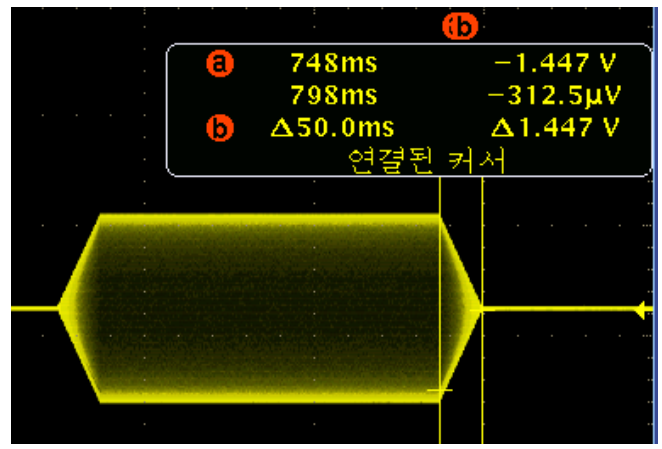

[그림 8] 기본 단속음 Fall 구간 측정

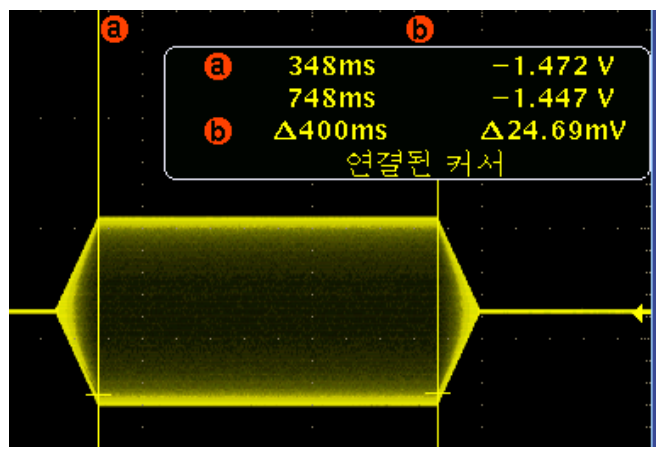

[그림 9] 기본 단속음 Plateau 구간 측정

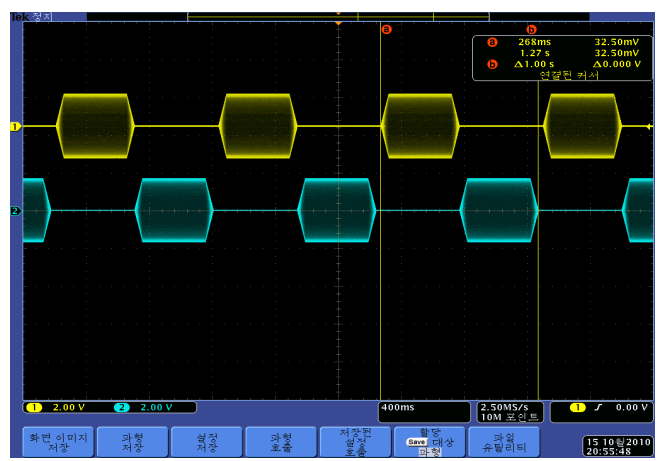

[그림 10] ABLB 검사 음 측정
그림 10 은 사운드카드의 2 개의 출력 채널에서 출력되 는 $\mathrm{ABLB}$ 검사음을 오실로스코프로 측정한 화면을 나타 낸다.

그림 $7,8,9$ 에서 사운드카드의 단일 출력 채널에서 출 력되는 기본 단속음은 $50 \mathrm{~ms}$ 의 Rise와 Fall 구간 그리고 $400 \mathrm{~ms}$ 의 Plateau 구간을 가진다. 그러므로 ABLB 기본 단속음이 $500 \mathrm{~ms}$ 로 정확하게 출력되는 것을 확인하였다. 또, 그림 10 에서 $\mathrm{ABLB}$ 검사 음이 2개의 출력 채널에서 교대로 출력되는 것을 확인하였다.

\section{5. 결론 및 향후 계획}

본 논문은 누가현상을 기초로 한 감각신경성 난청의 세부 병변을 감별하기 위한 검사 방법 중 하나인 $\mathrm{ABLB}$ 검사 시스템을 소프트웨어로 구현한 내용을 기술하였다.

본 논문의 자동 $\mathrm{ABLB}$ 검사 시스템은 컴퓨터를 이용 하여 소프트웨어로 구현함으로써, 기존의 전자기기로 구 현된 $\mathrm{ABLB}$ 검사 시스템에 비해 유연성을 갖는다. 특히 검사자가 수동으로 처리해야 하는 부분을 자동으로 수행 할 수 있도록 함으로써 검사자의 노력 및 시간을 줄일 수 있을 뿐만 아니라 검사 결과의 정확성을 향상시키는 장 점을 제공한다. 그리고 자동 $\mathrm{ABLB}$ 검사 소프트웨어의 검사 음을 디지털 오실로스코프를 이용하여 측정 한 결 과 ANSI S3.6-2004[10] 규격을 완벽하게 준수함을 확인 하였다.

현재 구현된 자동 $\mathrm{ABLB}$ 검사 소프트웨어는 피검자의 입력 장치로 키보드를 사용하고 있다. 이 같은 환경은 피 검자에게 불편을 줄 수 있다. 피검자가 보다 편하게 반응 할 수 있도록 하기 위해 전용 ABLB 입력 장치를 제공할 계획이다. 또한 자동 검사 모드뿐만 아니라 수동 및 Self $\mathrm{ABLB}$ 검사 모드를 지원하여 전용 청력검사기기 보다 더 나은 검사 환경을 지원 할 계획이다.

\section{참고문헌}

[1] 신승원 외 4인, “음압 보정을 통한 이동형 청력 검사 시스템 구현", 전기학회논문지, 제56권, 제6호, pp. 1157-1164, 6월, 2007.

[2] 이동훈 외 7인, "자동차폐가 가능한 웹 기반하 디지털 기도순음청력검사기기의 개발”, 대한이비인후과학회 지, 제50권, 제 10 호, pp. 860-868, 10월, 2007.

[3] 김진동, 신범주, 전계록, 왕수건, "다중모드 지원 자동 차폐 순음청력검사 시스템 개발", 한국산학기술학회논 
문지, 제10권, 제6호, pp. 1229-1236, 6월, 2009.

[4] 김진동, 전계록, 왕수건, 신범주, “미세증가감수지수 검사와 자기청력검사를 이용한 난청 유형의 감별 진 단”, 한국전기전자재료학회논문지, 제 22 권, 제 8 호, pp. 704-713, 8월, 2009.

[5] 강덕훈 외 6인, "PC 기반의 SISI 검사 소프트웨어 개 발”, 한국산학기술학회논문지, 제 11 권, 제4호, pp. 1325-1332, 4월, 2010.

[6] 김진동 외 8 인, "PC 기반 순음청력검사기를 위한 자동 보정시스템 개발", 한국산학기술학회논문지, 제11권, 제7호, pp. 2586-2594, 7월, 2010.

[7] 이상흔, "누가 현상과 청각 피로검사", 부산경남이비인 후과학회, 제7권, 제2호, pp. 242-250, 11월, 1996.

[8] Interacoustics, "AC40", http://www.interacoustics-us.com/ us_en/Pages/Product/Audiometers/_index.htm?prodid=9 047

[9] GSI, "GSI61", http://www.grasonstadler.com/index.php? option $=$ com content $\&$ view $=$ article $\&$ id $=3 \&$ Itemid $=12$

[10] ANSI(American National Standard Institute) S3.6-2004, "American National Standard Specification for audiometers", 2004.

\section{강 덕 훈(Kang Deok Hun)}

[준회원]

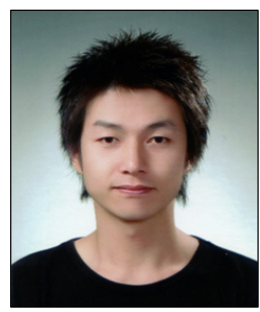

- 2009년 8월 현재 : 부산대학 교 대학원 바이오메디컬공학과 (공학석사과정)

<관심분야>

영상 및 음성 신호처리, 메디컬 소프트웨어 응용

\section{김 진 동(Kim Jin Dong)}

[정회원]

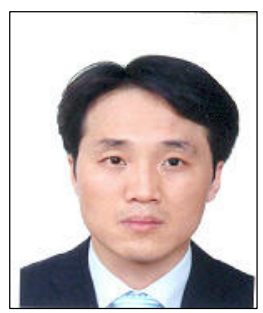

- 2006년 2월 : 부산대학교 대학원 의학과(의학석사)

- 2008년 3월 현재 : 부산대학 교 대학원 의공학협동과정

- 1999년 5월 현재 : 부산대학 교병원 이비인후과

\section{송 복 득(Song Bok Deuk)}

[정회원]

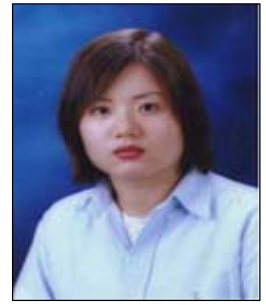

- 2004년 2월 : 동서대학교 소프트 웨어전문대학원 소프트웨어학과 (공학석사)

- 2009년 8월 현재 : 부산대학 교 대학원 바이오메디컬공학과 (공학박사과정)

<관심분야>

영상신호처리, 머신 비젼, 메디컬 소프트웨어 응용

\section{신 범 주(Bum Joo Shin)}

[정회원]

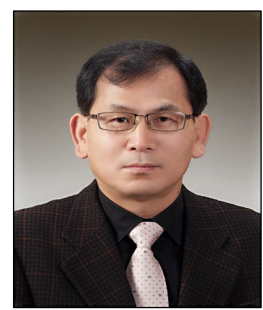

- 1991년 2월 : 경북대학교 대학원 컴퓨터공학과(공학석사)

- 1998년 8월 : 경북대학교 대학원 컴퓨터공학과(공학박사)

- 1987년 3월 2002년 2월 :한국 전자통신연구원 책임연구원

- 2006년 3월 현재 :부산대학교 바이오메디컬공학과 부교수

<관심분야>

센서시스템, 메디컬 소프트웨어 응용

\section{왕 수 건(Soo Geun Wang)}

[정회원]

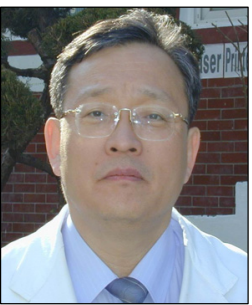

- 1981년 2월 : 부산대학교 대학원 의학과(의학석사)

- 1988년 2월 : 부산대학교 대학원 의학과(의학박사)

- 1987년 10월 현재 : 부산대학 교 의학전문대학원 교수

<관심분야>

신호처리, 생체계측, 의공학 